\title{
Metal ion binding and tolerance of bacteria cells in view of sensor applications
}

\author{
Jonas Jung $^{1}$, Anja Blüher ${ }^{1}$, Mathias Lakatos ${ }^{2}$, and Gianaurelio Cuniberti ${ }^{1}$ \\ ${ }^{1}$ Institute for Materials Science and Max Bergmann Center of Biomaterials, TU Dresden, \\ 01062 Dresden, Germany \\ ${ }^{2}$ Chair of Physical Chemistry, Measurement and Sensor Technology, TU Dresden, \\ 01062 Dresden, Germany
}

Correspondence: Jonas Jung (jonas.jung@tu-dresden.de)

Received: 13 April 2018 - Revised: 22 June 2018 - Accepted: 28 June 2018 - Published: 6 July 2018

\begin{abstract}
The biotechnological use of bacterial cells and cell components for the detection and accumulation of valuable substances, such as metals and rare earth elements in aqueous systems, is possible by utilizing innate binding characteristics of microorganisms. We have studied the bacteria cells of Lysinibacillus sphaericus JGB53 and Sporosarcina ureae ATCC 13881 to assess their potential applicability for the detection of rare earth elements, base metals or precious metals in water. First, we have demonstrated the interactions of the cells with the metal complexes of $\mathrm{Au}$, Ho and $\mathrm{Y}$ by studying the color changes of the respective solutions, scanning electron microscopy (SEM) imaging of the metal cluster decoration on the cell surfaces and cell growth tolerance tests. Based on these results, we have developed two potential sensor systems. A colorimetric sensor was established by applying gold nanoparticles (AuNPs) functionalized with surface-layer ( $S$-layer) proteins SslA of $S$. ureae ATCC 13881 or Slp1 of $L$. sphaericus JG-B53 for the selective detection of $\mathrm{YCl}_{3}$ up to $1.67 \times 10^{-5} \mathrm{~mol} \mathrm{~L}^{-1}$ in water. Additionally, a regenerative sensor layer of $S$-layer proteins on a thin gold film was developed for the detection of $1 \times 10^{-4} \mathrm{~mol} \mathrm{~L}^{-1} \mathrm{YCl}_{3}$ in water by surface plasmon resonance (SPR) spectroscopy.
\end{abstract}

\section{Introduction}

Water is becoming one of the most important resources of the 21 st century (Gleick, 1993). Currently, more than 2.1 billion people have no access to clean drinking water (WHO and UNICEF, 2017), which will become worse for more than 7 billion people by the year 2050 (UNWWAP, 2015). Considering the growing importance of fresh drinking water in the coming years, the detection and treatment of polluted water with new sensitive and specific methods is becoming more important.

The development of highly selective sensor-actuator systems for the sustainable use of water and resources is a central goal. The detection of low concentrations of metals from mining and industrial effluent (such as $\mathrm{In}, \mathrm{Ga}, \mathrm{Cu}$ or rare earth elements, REEs) but even more so the elimination and recovery of reusable metals are significant factors that have not yet been fully covered by conventional processes. For many of these metals, only a few elaborate detection methods are available so far, which are often tailored to very specific applications. This bottleneck can be overcome by nature, in this specific case by the use of microorganisms. Microorganisms can survive in extreme environmental conditions, even at high concentrations of metallic pollutants. They have developed interesting strategies, such as attaching toxic metals selectively to the so-called surface-layer ( $S$-layer) proteins (Pollman and Matys, 2007). This enables the use of whole cells as sensors or the recovery of metal ions from water by means of immobilizing the cells in matrix materials (Matys et al., 2004; Soltmann et al., 2003). Several bacteria species have been studied with regard to their metal binding capacities by bioadsorption. The vegetative cells and spores of various Bacillus strains, like B. cereus, B. megaterium and $B$. sphaericus, can bind a broad range of metal ions, including $\mathrm{Al}^{3+}, \mathrm{Cd}^{2+}, \mathrm{Cu}^{2+}, \mathrm{Ga}^{3+}, \mathrm{Ni}^{3+}, \mathrm{Pb}^{2+}$ and $\mathrm{U}^{4+}$, from natural drain water samples (Mathew et al., 2015; Selenska-Pobell et al., 1999). Caulobacter crescentus can adsorb a broad range 
of REEs (Park et al., 2016). L. sphaericus JG-A12 can bind $\mathrm{Au}^{3+}, \mathrm{Cu}^{2+}, \mathrm{Pd}^{2+}, \mathrm{Pt}^{2+}$ and $\mathrm{U}^{4+}$ (Fahmy et al., 2006; Merroun et al., 2005; Pollmann et al., 2006; Raff et al. 2003), whereas $L$. sphaericus JG-B53 is known to bind $\mathrm{Eu}^{3+}, \mathrm{Au}^{3+}$, $\mathrm{Pd}^{2+}$ and $\mathrm{Pt}^{2+}$ with a higher affinity to $\mathrm{Pd}^{2+}$ and $\mathrm{Au}^{3+}(\mathrm{Suhr}$ et al., 2014). Other concepts are based on the use of the purified $S$-layer proteins of these bacteria for immobilization matrices, the attachment of fusion proteins or the detection of molecules like $\mathrm{Pt}(\mathrm{II})$ porphyrin (Ladenhauf et al., 2015; Mateu et al., 2014; Neubauer et al., 1993, 1994; Scheicher et al., 2009; Weinert et al., 2015).

Currently, there are only few approaches available using $S$-layer proteins as a detection layer in water or on surfaces. One example is the detection of uranyl in real time by using low-frequency impedance spectroscopy (Conroy et al., 2010). Another more recent approach is the use of $S$ layer proteins of $L$. sphaericus JG-A12 to functionalize gold nanoparticles (AuNPs) and the establishment of a colorimetric sensor based on the color change by particle agglomeration in the presence of $\mathrm{As}(\mathrm{V})$ ions (Lakatos et al., 2015).

Hereinafter, the development of a new sensor concept based on bacteria cells and surface-layer proteins for the detection of noble metals, as well as of rare earth elements is going to be presented. Two bacterial strains, L. sphaericus JG-B53 and S. ureae ATCC 13881, have been investigated for their tolerance and binding properties with respect to $\mathrm{KAuCl}_{4}, \mathrm{CuSO}_{4}, \mathrm{Sm}\left(\mathrm{NO}_{3}\right)_{3}, \mathrm{Ho}\left(\mathrm{NO}_{3}\right)_{3}$ and $\mathrm{YCl}_{3}$. Preliminary studies were realized by whole-cell systems. According to these results, two possible sensor concepts using specially extracted surface-layer proteins from these two bacterial strains were developed for the detection of $\mathrm{YCl}_{3}$ : (i) a simple and rapid colorimetric method based on the agglomeration of AuNPs, and a color shift in the presence of the analyte, and (ii) a regenerative robust surface functionalization for surface plasmon resonance (SPR) spectroscopy.

\section{Materials and methods}

\subsection{Bacteria growth}

The bacterial strains L. sphaericus JG-B53 and S. ureae ATCC 13881 were grown in liquid nutrient broth $\left(5 \mathrm{~g} \mathrm{~L}^{-1}\right.$ Bacto $^{\mathrm{TM}}$ Peptone, Becton, Dickinson and Company, Sparks, USA, and $3 \mathrm{~g} \mathrm{~L}^{-1}$ meat extract, Merck, Germany) at $30^{\circ} \mathrm{C}$ under constant shaking. All the samples were harvested at the end of the exponential growth phase.

\subsection{Metal binding activity and metal tolerance tests of bacteria}

The metal binding activity and the metal tolerance of the bacteria species were studied by incubation of the bacteria with various metal salt solutions in different concentrations. Specifically, $2 \mathrm{~mL}$ harvested cells was washed twice through centrifugation at $3800 \mathrm{~g}$ for $5 \mathrm{~min}$. The pel-

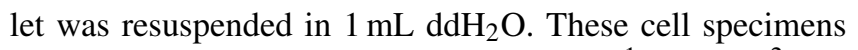
were incubated for 2 days in $1 \mathrm{~mL} 1 \times 10^{-1}, 1 \times 10^{-2}$ and $1 \times 10^{-3} \mathrm{molL}^{-1}$ of $\mathrm{CuSO}_{4}, \mathrm{Ho}\left(\mathrm{NO}_{3}\right)_{3}, \mathrm{Sm}\left(\mathrm{NO}_{3}\right)_{3}, \mathrm{YCl}_{3}$, or in $1 \mathrm{~mL} 1 \times 10^{-2}$ and $1 \times 10^{-3} \mathrm{~mol} \mathrm{~L}^{-1} \mathrm{KAuCl}_{4}$.

For the evaluation of the metal binding activity, incubated bacteria cells were adsorbed on silicon wafers and dried for at least 2 days. The dried specimens were characterized by scanning electron microscopy (SEM; Zeiss DSM 982 Gemini, Zeiss, Oberkochen, Germany) along with WSXM software (Horcas et al., 2007).

For the metal tolerance tests, $100 \mu \mathrm{L}$ of the metal ion incubated bacteria cells was grown for 3 to 5 days on agar plates $\left(15 \mathrm{~g} \mathrm{~L}^{-1}\right.$ agar, $8 \mathrm{~g} \mathrm{~L}^{-1}$ NB-medium Bacto Nutrient Broth, Difco Laboratories, Canada) and the number of colonyforming units was counted.

\subsection{Colorimetric sensor using $S$-layer-functionalized AuNPs}

\subsubsection{S-layer extraction}

The extraction of the $S$-layer proteins of $S$. ureae ATCC 13881 (SslA) and of L. sphaericus JG-B53 (Slp1) was carried out as described by Blüher (Blüher et al., 2015). The resulting solution contained crystalline $S$ layers (tubes and sheets) and monomeric fractions, which were completely disassembled into monomers in $6 \mathrm{~mol} \mathrm{~L}^{-1}$ guanidine hydrochloride, followed by centrifugation at $14000 \mathrm{~g}$ for $30 \mathrm{~min}$, and dialysis against a $5 \times 10^{-4} \mathrm{~mol} \mathrm{~L}^{-1}$ TRIS buffer for $4 \mathrm{~h}$. The $S$ layer monomer solution was stored at $4{ }^{\circ} \mathrm{C}$ until final use (a few days up to 1 week).

\subsubsection{Synthesis and characterization of the AuNPs}

Spherical AuNPs with a diameter of $20-30 \mathrm{~nm}$ were synthesized using a modified Turkevich method (Turkevich et al., 1951). In detail, $100 \mathrm{~mL}$ of a $5 \times 10^{-4} \mathrm{~mol} \mathrm{~L}^{-1} \quad \mathrm{HAuCl}_{4} \cdot 3 \mathrm{H}_{2} \mathrm{O}$ was boiled under constant stirring, before $2 \mathrm{~mL}$ of a $1 \%$ sodium citrate solution was added. After a few minutes, the color changed from light yellow to burgundy red. Typically, the reaction and formation of the colloidal AuNPs is completed after further $60 \mathrm{~min}$ of constant stirring. Afterwards, the colloidal solution was slowly cooled down to room temperature. The characterization of the spherical AuNPs was carried out by UV-VIS spectroscopy (Varian Cary 100 inc., Canterbury, Australia) and SEM. Before further use, the absorption maximum of the spherical AuNPs (20-30 nm in diameter) was adjusted to $\mathrm{OD}=1$ at $525 \mathrm{~nm}$.

\subsubsection{Functionalization of AuNPs and colorimetric test}

To investigate active sensor particles in solutions, the previously synthesized AuNPs were functionalized with the monomeric $S$-layer proteins. 


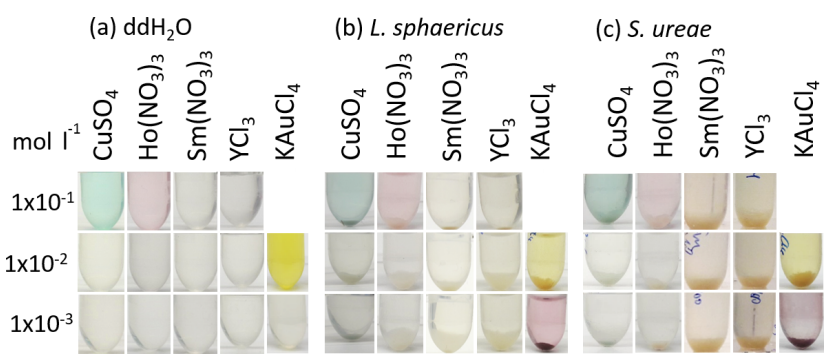

Figure 1. Incubation of L. sphaericus JG-B53 and S. ureae ATCC 13881 in different analyte solutions at three concentrations. The reference was a metal salt solution in water without bacteria cells.

The required concentration of the proteins for the complete functionalization and stabilization of the AuNPs was determined according to Geoghegan and Ackerman (1977). Briefly, a serial dilution of the $S$-layer protein solution was prepared, starting from $1 \mathrm{mg} \mathrm{mL}^{-1}$ to $1 \times 10^{-4} \mathrm{mg} \mathrm{mL}^{-1}$. Typically $50 \mu \mathrm{L}$ final $S$-layer solution was mixed with $100 \mu \mathrm{L}$ AuNP solution $\left(\mathrm{OD}_{525}=1\right)$. After an adsorption time of $30 \mathrm{~min}, 10 \mu \mathrm{L} 10 \% \mathrm{NaCl}$ was added to each of the AuNP protein mixtures. If the particles were insufficiently stabilized by the protein, the color of the AuNP protein mixture turned from red to blue. Subsequently, only mixtures of successfully protein-stabilized AuNP solutions were used for the colorimetric metal ion detection tests.

To prepare a final volume of a $10 \mathrm{~mL}$ solution of $S$-layerfunctionalized AuNPs, the ratios were scaled up. The mixture of AuNPs and $S$-layer proteins was kept overnight at $4{ }^{\circ} \mathrm{C}$ under slight constant shaking. Unbound protein was separated by centrifugation at $3000 \mathrm{~g}$ for $30 \mathrm{~min}$ at $4{ }^{\circ} \mathrm{C}$. The centrifugation was repeated up to 3 times. The supernatant was carefully discarded and the pellet of $S$-layer-functionalized AuNPs was resuspended in $0.1 \%$ polyvinyl alcohol (PVA) with $\mathrm{OD}_{525}=1$. PVA was used to prevent the particles from aggregation via unspecific interaction of insufficiently covered gold surfaces with the analytes.

For the colorimetric test $\mathrm{YCl}_{3}$ was used as the analyte. According to the protocol, $50 \mu \mathrm{L}$ of $\mathrm{YCl}_{3}$ solutions of different concentrations $\left(2.5 \times 10^{-1}\right.$ to $\left.5 \times 10^{-6} \mathrm{~mol} \mathrm{~L}^{-1}\right)$ were added to $100 \mu \mathrm{L}$ of the $S$-layer-functionalized AuNPs $(\mathrm{OD}=1)$. AuNPs without $S$-layer functionalization, stabilized by $1 \%$ PVA, were used as the reference.

\subsection{SPR spectroscopy}

The setup for surface plasmon resonance spectroscopy is based on a Kretschmann configuration. The instrument was developed at the Fraunhofer Institute IOF in Jena, Germany. For all the measurements TOPAS ${ }^{\odot}$ SPR chips (produced by KDS Radeberger Präzisions-Formen und Werkzeugbau GmbH, Großröhrsdorf, Germany) were used, with a $50 \mathrm{~nm}$ thick gold layer and a surface area of $3 \times 12 \mathrm{~mm}$ (Kretschmann, 1971; Hofmann and Danz, 2008). The tem-

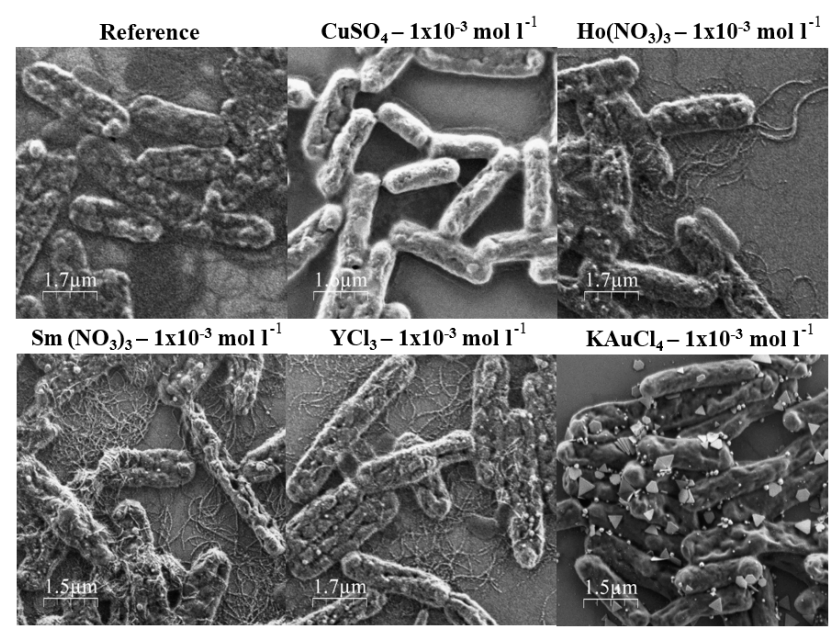

Figure 2. SEM images from L. sphaericus JG-B53 cells from the metal binding test after 2 days' incubation with $1 \times 10^{-3} \mathrm{~mol} \mathrm{~L}^{-1}$ $\mathrm{CuSO}_{4}, \mathrm{Ho}\left(\mathrm{NO}_{3}\right)_{3}, \mathrm{Sm}\left(\mathrm{NO}_{3}\right)_{3}, \mathrm{YCl}_{3}$ and $\mathrm{KAuCl}_{4}$ solutions.

perature was kept constant at $25^{\circ} \mathrm{C}$ using a water cooling system for the microfluidic sample chamber. Before measurement, all SPR chips were cleaned with $\mathrm{EtOH}$ and $\mathrm{ddH}_{2} \mathrm{O}$. To facilitate the recrystallization of the $S$-layer proteins on the surface, the surface of the SPR chips was activated through incubation with $1 \times 10^{-2} \mathrm{~mol} \mathrm{~L}^{-1} \mathrm{MgCl}_{2}$, followed by the addition of the monomeric $S$-layer proteins. The adsorption of the $S$-layer proteins on the surface as well as the interaction of the $S$-layer-protein-functionalized surfaces with the analyte $\mathrm{YCl}_{3}$ were monitored by online measurements.

\section{Results and discussion}

This study focused on the development of selective biohybrid sensor systems for metal ions in water. For whole-cell sensor applications, the interactions of bacteria cells of $L$. sphaericus JG-B53 and S. ureae ATCC 13881 with metal salts were investigated optically during incubation (e.g., color changes, sedimentation) and subsequently by SEM characterization and growth tests. The aim of these tests was to determine the interactions of bacterial cells with metal salt solutions and to predict which $S$ layer can be used for the detection of the respective metal. Utilizing the specific binding properties of $S$-layer proteins, two sensor concepts were developed to selectively detect $\mathrm{YCl}_{3}$ in water.

\subsection{Metal binding activity}

To study the metal binding activity and the metal tolerance, bacteria cells were incubated with metal salt solutions of different concentrations for 2 days (Fig. 1).

Within 2 days of incubation, most of the bacteria cells settled on the ground of the tubes by sedimentation. These sediments are more pronounced for the samples of $S$. ureae 


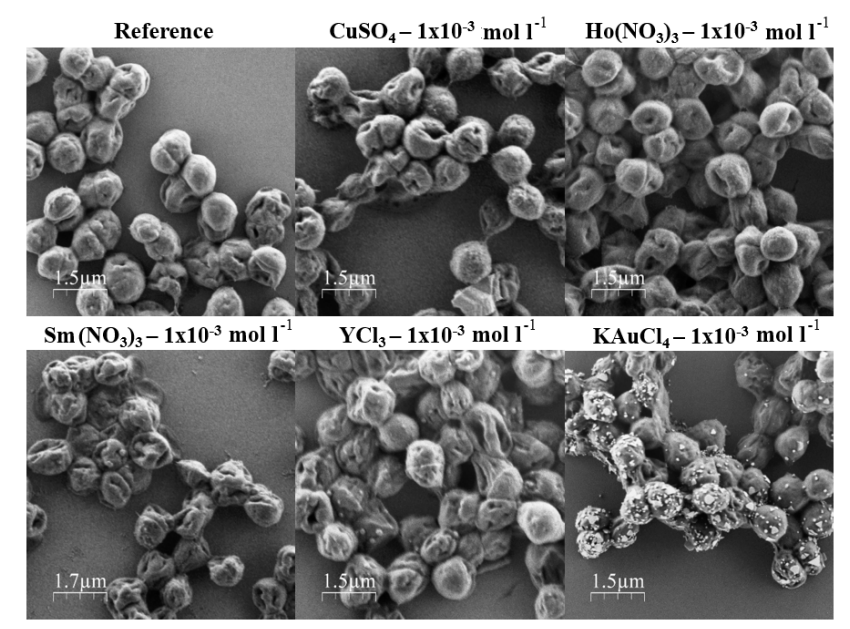

Figure 3. SEM images from $S$. ureae ATCC 13881 cells from the metal binding test after 2 days' incubation with $1 \times 10^{-3} \mathrm{~mol} \mathrm{~L}^{-1}$ $\mathrm{CuSO}_{4}, \mathrm{Ho}\left(\mathrm{NO}_{3}\right)_{3}, \mathrm{Sm}\left(\mathrm{NO}_{3}\right)_{3}, \mathrm{YCl}_{3}$ and $\mathrm{KAuCl}_{4}$ solutions.

ATCC 13881 than L. sphaericus JG-B53. This can be explained by the flagella and the higher motility of $L$. sphaericus JG-B53.

A first indication of the interaction of the metals with the bacteria cells could be a color change of the respective solution for colored metal complexes, e.g., for $\mathrm{Ho}, \mathrm{Cu}$ or $\mathrm{Au}$. Solutions with metal ions of Sm and Y are always colorless and did not change during incubation. For $\mathrm{Cu}$ and Ho ions there were no visible reactions observed. Only for the Au complex does the solution decolorize $\left(1 \times 10^{-2} \mathrm{~mol} \mathrm{~L}^{-1}\right)$ or change from yellow to red or purple $\left(1 \times 10^{-3} \mathrm{~mol} \mathrm{~L}^{-1}\right)$. Both effects could be attributed to the formation of AuNPs (Fig. 6) (Suhr et al., 2016; Turkevich et al., 1951).

A possible explanation for these cluster formation processes could be the well-known reducing effects of many cell envelope components, which has been shown for the formation of AuNPs on the cell surface of L. sphaericus JG-A12 (Jankowski et al., 2010; Suhr et al., 2016). The nanoparticle formation due to $\mathrm{pH}$ effects in the presence of the cells can be excluded because there were no significant changes of the $\mathrm{pH}$ values compared to pure metal salt solutions (Supplement).

In order to study cluster or metal nanoparticle formation in the presence of the cells in more detail, corresponding samples were examined in SEM (see Figs. 2 and 3 and the Supplement). In contrast to the results of Fig. 1, heterogeneous nanoparticle formation on the cell surface was present in all samples, except the bacterial cells incubated with $\mathrm{CuSO}_{4}$ (all concentrations), $\mathrm{Sm}\left(\mathrm{NO}_{3}\right)_{3}$ (all concentrations) or $\mathrm{Ho}\left(\mathrm{NO}_{3}\right)_{3}\left(1 \times 10^{-1} \mathrm{~mol} \mathrm{~L}^{-1}\right)$ (Figs. 2 and 3). Additionally, the flagella of $L$. sphaericus JG-B53 were metallized by incubation with $1 \times 10^{-2}$ and $1 \times 10^{-3} \mathrm{~mol} \mathrm{~L}^{-1}$ $\mathrm{Sm}\left(\mathrm{NO}_{3}\right)_{3}$ (Fig. 2).
Similar to the observations of the incubated solutions, the decoration with AuNPs was clearly visible for both tested bacterial strains, regardless of the concentration of the $\mathrm{KAuCl}_{4}$ solution. The formed gold clusters were widely distributed on the cell surface and had a broad size and shape distribution in the range of a few nanometers up to several hundred nanometers. In the L. sphaericus samples, the higher $\mathrm{pH}(3.03)$ at $1 \times 10^{-3} \mathrm{~mol} \mathrm{~L}^{-1}$ induced more heterogeneous round or triangular AuNP shapes, which were not present at lower $\mathrm{pH}$ values.

Clear differences depending on the bacterial strains used were visible for the interaction with $\mathrm{YCl}_{3}$ and $\mathrm{Ho}\left(\mathrm{NO}_{3}\right)_{3}$. For L. sphaericus JG-B53 the cluster formation was predominantly along the flagella (Fig. 2), while for $S$. ureae ATCC 13881 the clusters were widely distributed on the cell surface (Fig. 3). The formed clusters were distinctly smaller and more densely packed on the respective surfaces compared to the decoration with AuNPs.

In conclusion L. sphaericus JG-B53 can form nanoparticles on the cell surface or the flagella by the reduction of $\mathrm{Ho}\left(\mathrm{NO}_{3}\right)_{3}, \mathrm{KAuCl}_{4}, \mathrm{Sm}\left(\mathrm{NO}_{3}\right)_{3}$ and $\mathrm{YCl}_{3}$ metal salts, for all the concentrations used. Metal binding and nanoparticle formation of $S$. ureae cells was demonstrated for all concentrations of $\mathrm{KAuCl}_{4}$ and $\mathrm{YCl}_{3}$ too, as well as for $\mathrm{Ho}\left(\mathrm{NO}_{3}\right)_{3}$ at $1 \times 10^{-2}$ and $1 \times 10^{-3} \mathrm{~mol} \mathrm{~L}^{-1}$.

\subsection{Metal tolerance growth test}

The main purpose of the metal tolerance test was to investigate the viability of the cells as a function of different metal salts and concentrations. With regard to a possible application as a whole-cell sensor, not only does the interaction with the cell surface play a role, but the effect on the vitality of the cells plays a central role too. The metal tolerance studies were performed with metal salt solutions of $\mathrm{CuSO}_{4}$, $\mathrm{Ho}\left(\mathrm{NO}_{3}\right)_{3}, \mathrm{Sm}\left(\mathrm{NO}_{3}\right)_{3}, \mathrm{YCl}_{3}$ and $\mathrm{KAuCl}_{4}$ for concentrations of $1 \times 10^{-1}, 1 \times 10^{-2}$ and $1 \times 10^{-3} \mathrm{~mol} \mathrm{~L}^{-1}$. The results of the metal salt tolerance tests are summarized for L. sphaericus JG-B53 and S. ureae ATCC 13881 after 5 days of growth (Fig. 4). Reference plates showed 10000 colony-forming units (CFUs) and were established as having $100 \%$ bacterial viability (data not shown). For plates with high CFU counts, only one-quarter was counted, multiplied by 4 to amount for the whole plate and then by 10 to take the $1: 10$ dilution of the sample into account.

Regardless of the metal and bacterial strains used, high metal ion concentrations in the solution during the incubation could be associated with a high mortality of the cells. This was always reflected by low growth rates. In contrast, lower metal salt concentrations significantly increased the growth rates up to comparable values of untreated references. For $S$. ureae ATCC 13881 all tested metal salt solutions completely inhibited growth for 5 days of incubation at concentrations equal to or higher than $1 \times 10^{-2} \mathrm{~mol} \mathrm{~L}^{-1}$. At the lowest concentrations $\left(1 \times 10^{-3} \mathrm{~mol} \mathrm{~L}^{-1}\right)$ of $\mathrm{CuSO}_{4}, \mathrm{Sm}\left(\mathrm{NO}_{3}\right)_{3}$ and 

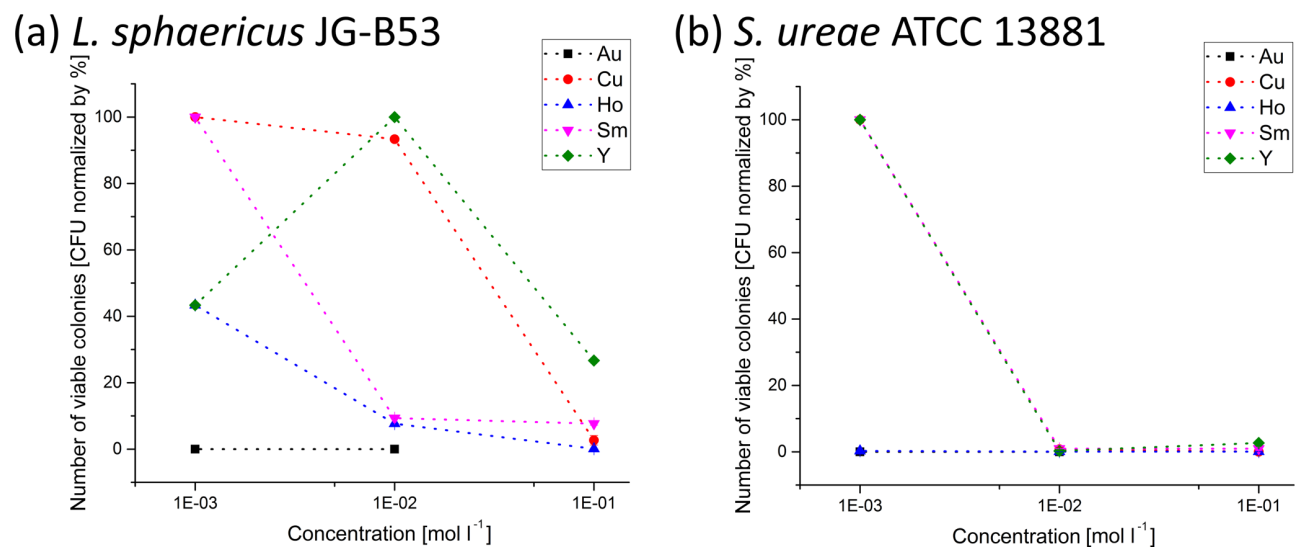

Figure 4. Metal tolerance of (a) L. sphaericus JG-B53 and (b) S. ureae ATCC 13881 for different metal salts and concentrations determined for growth on agar plates after 2 days of incubation. The colonies were counted after 5 days and normalized to the CFU count of reference plates without metal salts.

$\mathrm{YCl}_{3}$, S. ureae grew comparable to the reference. Therefore metal tolerance of $S$. ureae ATCC 13881 can only be detected for these three samples.

Exceptions to this overall trend were the series of experiments with $\mathrm{Ho}\left(\mathrm{NO}_{3}\right)_{3}$ and $\mathrm{KAuCl}_{4}$, which consistently showed poor growth rates for all concentrations. This suggests a high interaction potential, as confirmed by the investigations of metal cluster deposition with SEM. Both bacterial strains did not grow in the presence of gold metal ions. This might either be due to the gold salt or the very low $\mathrm{pH}$ value of this samples. Standard $\mathrm{pH}$ values for the growth of bacteria from literature are in the range of 6.8-8.5 for $L$. sphaericus JG-B53 and around 8.7 for $S$. ureae ATCC 13881 (Goldman and Wilson, 1977; Suhr et al., 2014; Yousten and Wallis, 1987). Taking all $\mathrm{pH}$ values into account, growth was only possible for $\mathrm{pH}$ values of 3.89 and higher. However, there seems to be no clear correlation between higher $\mathrm{pH}$ values and the growth rates because the lowest growth with some colonies still present was measured at a $\mathrm{pH}$ of 6.42 for $1 \times 10^{-1} \mathrm{~mol} \mathrm{~L}^{-1} \mathrm{Ho}\left(\mathrm{NO}_{3}\right)_{3}$. However, the $\mathrm{pH}$ values are not the only factor of growth inhibition. At a pH of $6.5 \pm 0.1$ for bacterial cells of $S$. ureae ATCC 13881 incubated with $1 \times 10^{-3} \mathrm{~mol} \mathrm{~L}^{-1} \mathrm{Ho}\left(\mathrm{NO}_{3}\right)_{3}$ ( $\mathrm{pH}$ of 6.64 ), no growth was visible, while for the same concentrations of $\mathrm{Sm}\left(\mathrm{NO}_{3}\right)_{3}(\mathrm{pH}$ of 6.42) and $\mathrm{YCl}_{3}$ (pH of 6.37), strong growth was measured. All samples with no inhibition had $\mathrm{pH}$ values of 5.82 or higher. Therefore a higher $\mathrm{pH}$ value overall affects the growth in a positive manner, while $\mathrm{Ho}\left(\mathrm{NO}_{3}\right)_{3}$ still inhibits growth at this high $\mathrm{pH}$. According to literature, this is also supported by the higher optimal growth $\mathrm{pH}$ of 8.7 for $S$. ureae ATCC 13881 (Goldman and Wilson, 1977).

In direct comparison of both bacterial strains, $L$. sphaericus JG-B53 was significantly more robust or less susceptible to interactions with the majority of the metal ions studied than S. ureae ATCC 13881 (Fig. 4).

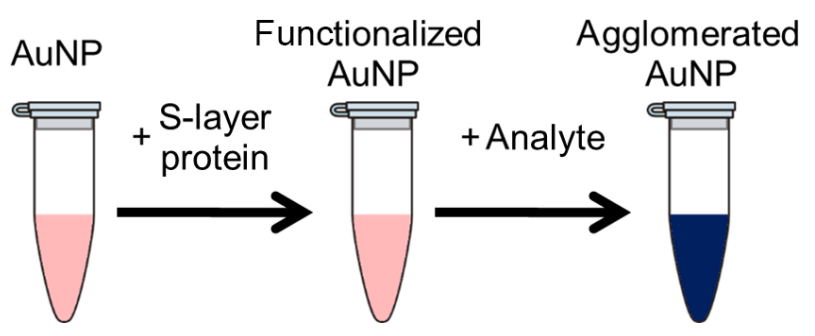

Figure 5. Schematic illustration of the colorimetric detection method using $S$-layer-functionalized AuNPs.

The experiments with Y ions took a special position. Almost continuous growth rates above $30 \%$ were observed for L. sphaericus JG-B53 and Y. This indicates a reduced interaction. No correlation between the metal salt concentration and growth could be found for $1 \times 10^{-2} \mathrm{~mol} \mathrm{~L}^{-1} \mathrm{YCl}_{3}$, and viability rates were $30-40 \%$ for the remaining two concentrations. For S. ureae ATCC 13881 the CFU count was only increased at low concentrations $\left(1 \times 10^{-3} \mathrm{~mol} \mathrm{~L}^{-1}\right)$. In association with the formation and deposition of metal clusters in the presence of cells, a different behavior for the decoration with metal clusters depending on the cell type has already been observed for $\mathrm{YCl}_{3}$ (Sect. 3.1.).

Nanoparticle formation was observed on SEM images of bacteria incubated with $\mathrm{Ho}\left(\mathrm{NO}_{3}\right)_{3}, \mathrm{KAuCl}_{4}, \mathrm{Sm}\left(\mathrm{NO}_{3}\right)_{3}$ and $\mathrm{YCl}_{3}$. While some of these samples grew less when compared with the reference due to the influence of the metal salt solutions, they still bound the metal salts on their surface. For whole-cell sensing and water cleaning applications with living cells, L. sphaericus JG-B53 proved to be more robust, with only high growth inhibition at $1 \times 10^{-3} \mathrm{~mol} \mathrm{~L}^{-1}$ of metal ion concentrations. S. ureae ATCC 13881, while being very prone to growth inhibition due to the influence of metal ions at higher concentrations, could still be used for applications with lower concentrations in the environment. 


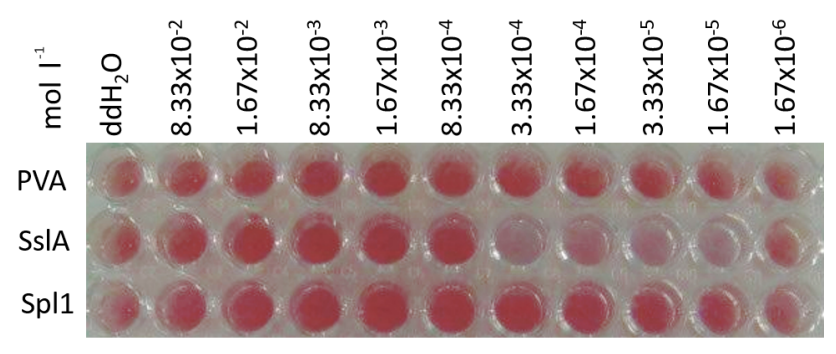

Figure 6. Colorimetric assay of PVA, SslA (S. ureae ATCC 13881) and Slp1 (L. sphaericus JG-B53)-functionalized AuNPs upon addition of different concentrations of $\mathrm{YCl}_{3}$.

To circumvent these limitations, single-use sensors or recovery systems will be a possible solution.

In general, the different interaction behavior of the two bacterial strains $L$. sphaericus JG-B53 and S. ureae ATCC 13881 for Y ions can be exploited for specific sensor applications. This will be demonstrated in the following section by the specific functionalization of a sensor surface and the formation of active sensor layers (transducer) with the $S$-layer proteins of these bacterial strains.

\subsection{Sensor applications}

\subsubsection{Colorimetric sensor system}

Typically, a colloidal solution of spherical AuNPs exhibits an intense red color based on its absorption maximum at 510 to $560 \mathrm{~nm}$. This absorption arises from the collective oscillation of the free valance electrons of the nanoparticles, the socalled surface plasmon resonance (SPR), by excitation with an electromagnet field, e.g., white light. The SPR is strongly related to the material, shape and size as well as the surrounding media of the nanoparticles. In particular, the dependency of the SPR from the surrounding media can be used to build up sensor applications. A change of the dielectric environment of the nanoparticles, for example by nanoparticle functionalization or a change of the refractive index of the solvent, results in smaller shifts of the absorption maxima. Stronger shifts can be achieved by particle clustering or aggregation. Due to interparticle plasmon coupling, the SPR signal will be strongly red-shifted. The color of the particle solution turns from red to purple or blue (Fig. 5). This color shift can be observed by the naked eye and is used as the basic principle for a huge number of colorimetric detection methods (Wilson, 2008; Zhao et al., 2008).

For a highly specific detection of an analyte, the surface functionalization of the nanoparticles is of significant importance. According to the results of the whole-cell systems (Sects. 3.1. and 3.2), $S$-layer proteins from bacteria cells of $S$. ureae ATCC 13881 ( $S$-layer protein SslA) and L. sphaericus JG-B53 ( $S$-layer protein Slp1) have been used for nanoparticle functionalization. The potential of a colorimetric sensor was investigated by using $\mathrm{YCl}_{3}$ as the analyte. PVA- (a)

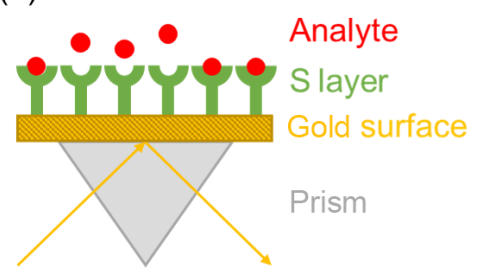

(b)

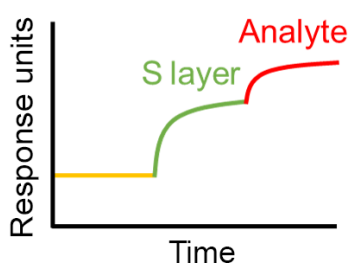

Figure 7. Schematic representation of the biofunctionalization of the SPR-chip and the sensor principle after addition of the analyte.

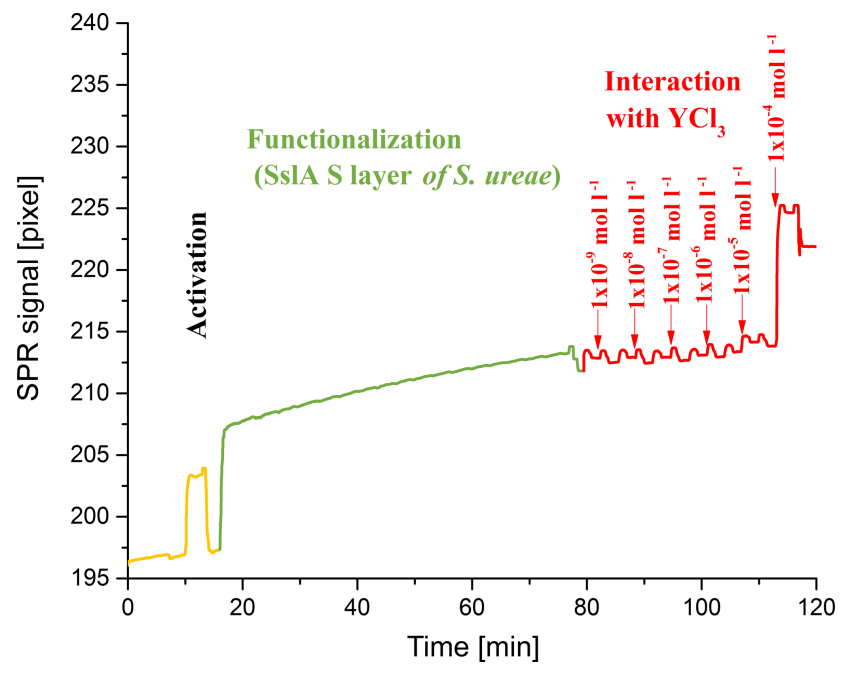

Figure 8. SPR measurement with SslA $S$-layer protein of $S$. ureae ATCC 13881 and $\mathrm{YCl}_{3}$.

stabilized AuNPs without $S$-layer functionalization, which should not interact with $\mathrm{YCl}_{3}$, were used as the reference (Fig. 6).

As indicated by the color change, only SslAfunctionalized AuNPs interacted with $\mathrm{YCl}_{3}$. Slp1functionalized as well as PVA-stabilized AuNPs showed no color change by the addition of $\mathrm{YCl}_{3}$. This is in line with former results of the whole-cell tests and the metal cluster decoration on the surface of $S$. ureae ATCC 13881 cells (Sect. 3.1). The visible color change from red to blue was in the range of $3.33 \times 10^{-4}$ to $1.67 \times 10^{-5} \mathrm{~mol} \mathrm{~L}^{-1}$ $\mathrm{YCl}_{3}$. Above and below these concentrations, the solutions remained unchanged.

The complex binding mechanisms of metal ions by $S$-layer proteins involve multiple functional groups such as $\mathrm{NH}_{2}$, $\mathrm{NH}, \mathrm{OH}, \mathrm{CO}, \mathrm{COOH}, \mathrm{SH}$ and $\mathrm{PO}_{4}$ (Raff et al., 2002). For $\mathrm{YCl}_{3}$ concentrations below $1.67 \times 10^{-5} \mathrm{~mol} \mathrm{~L}^{-1}$ no color change was visible due to the repulsive Coulomb interactions of the positively charged surface of $S$-layer-functionalized AuNPs (Lakatos et al., 2015). An increase of the $\mathrm{YCl}_{3}$ concentration induces the cross-linkage and aggregation of the $S$-layer-functionalized AuNPs, as indicated by the color change. Roosen-Runge et al. (2013) have demonstrated the 
interaction of $\mathrm{Y}^{3+}$ ions with the carboxylate groups of proteins. At concentrations above $3.33 \times 10^{-4} \mathrm{~mol} \mathrm{~L}^{-1}$ no more color changes of the solutions were visible. This can be explained by the increasing number of free $\mathrm{Y}$ ions and a saturation of all binding sites on the $S$-layer proteins. The mechanism of cross-linkage between the particles does not take place (Lakatos et al., 2015).

To develop robust, selective and sensitive sensor concepts, further studies on the specific binding characteristics of the proteins as well as the metal ion to $S$-layer protein interactions are necessary. According to official regulations a detection limit below $5 \times 10^{-9} \mathrm{~mol} \mathrm{~L}^{-1}$ for $\mathrm{Y}$ ions should be reached by further optimizing the system. The sensitivity could be increased by varying the size of the AuNPs, the functionalization method and the optical density of the sensor solution.

\subsubsection{SPR spectroscopy sensor system}

SPR spectroscopy is a highly sensitive and flexible method for the label-free detection of biomolecular interactions and has been shown to detect very small molecules like DNA up to $2 \times 10^{-9} \mathrm{~mol} \mathrm{~L}^{-1}$ (Kretschmann and Raether, 1968; Kretschmann, 1971; Homola et al., 1999; Otto, 1968; Wood, 1902). The detection method is based on changes of the evanescent field resulting from plasmon resonance excitation on a metal surface when light of a given wavelength hits this surface at a certain angle (Wood, 1902; Fano, 1941). This angle depends on the refractive index of the medium within a boundary layer of approximately $200 \mathrm{~nm}$ thickness on the metal. A change of the refractive index results in a shift of the SPR minimum. Therefore, not only can adsorption and binding of molecules affect the SPR spectroscopy measurement, but also variations in temperature and composition in the adjacent medium of the sensor surface. In the present work an SPR spectrometer was used as a quantitative adsorption sensor. The binding of $S$-layer proteins and the subsequent binding of $\mathrm{YCl}_{3}$ was measured online (Fig. 7).

After an activation step, $S$-layer recrystallization processes on the gold surface were visible within the next $60 \mathrm{~min}$, before the signal reached a plateau (Fig. 8). The successful binding and the stability of the protein layer on the surface was evident due to the constant signal at the same level after this functionalization process (despite cleaning processes with $\mathrm{ddH}_{2} \mathrm{O}$ ).

The tested analyte concentration of $1 \times 10^{-4} \mathrm{~mol} \mathrm{~L}^{-1}$ led to a strong rise of the signal. A further increase of the $\mathrm{YCl}_{3}$ concentration up to $5 \times 10^{-3} \mathrm{~mol} \mathrm{~L}^{-1}$ did not result in an increase of the signal. The temporary small increase of the signal by the addition of lower concentrations of $\mathrm{YCl}_{3}$ is due to differences of the refraction index compared with $\mathrm{ddH}_{2} \mathrm{O}$.

In conclusion, the detection of $\mathrm{YCl}_{3}$ was possible at a concentration of $1 \times 10^{-4} \mathrm{~mol} \mathrm{~L}^{-1}$. This concentration already occupied all available binding sites on the $S$-layer protein layer attached to the gold surface. Together with the linearity of the signal established in preliminary experiments, a quantitative determination of an unknown amount of $\mathrm{YCl}_{3}$ was possible.

The regeneration of the gold surface through several washing steps and the use of plasma cleaning was also tested, but this has to be optimized (data not shown). SPR spectroscopy can be improved by varying the functionalization of the chip and by using more than one $S$ layer on a single chip, in order to develop single-chip detection systems for several metal ions and rare earth elements.

Furthermore, a combination of both methods, the nanoparticle-based assay and the surface-based method, will enable the sensitivity and selectivity of the SPR signal to be obtained.

\section{Conclusions}

In summary, new sensor concepts were presented, based on the interaction of the bacterial strains $S$. ureae ATCC 13881 and L. sphaericus JG-B53 and their surface proteins (SslA and Spl1) with different ions of noble metals and rare earth elements, e.g., $\mathrm{Cu}, \mathrm{Au}, \mathrm{Sm}, \mathrm{Ho}$ and $\mathrm{Y}$. Metal binding and cluster formation were clearly demonstrated for whole cells of both bacteria in contact with Au, Ho and Y. As revealed by SEM, these processes are different for $S$. ureae ATCC 13881 (all over the cell surface) and L. sphaericus JG-B53 (mostly at flagella). Subsequently, the biofunctionalization and molecular recognition of the extracted $S$-layer proteins were investigated for two kinds of optical sensors in contact with $\mathrm{Y}$ ions. By using a simple colorimetric assay, based on the aggregation of $S$-layer-functionalized AuNPs and the resulting color shift, a detection limit of $1.67 \times 10^{-5} \mathrm{~mol} \mathrm{~L}^{-1}$ $\mathrm{YCl}_{3}$ for $S$. ureae ATCC 13881 and SslA was achieved. In contrast, for Spl1 of L. sphaericus JG-B53, no such signal was found. First studies on $S$-layer-functionalized SPR spectroscopy revealed that this concept can easily be transferred to commercially available systems.

The huge variety of naturally occurring and biological active $S$-layer proteins opens up a wide range of possibilities for the detection of different metal ions in water.

Data availability. The underlying measurement data are not publicly available and can be requested from the authors if required.

Supplement. The supplement related to this article is available online at: https://doi.org/10.5194/jsss-7-433-2018-supplement.

Competing interests. The authors declare that they have no conflict of interest. 
Special issue statement. This article is part of the special issue "Dresden Sensor Symposium 2017". It is a result of the Dresden Sensor Symposium 2017, Dresden, Germany, 4-6 December 2017.

Acknowledgements. The results presented were developed in close cooperation with the project partners of the HelmholtzZentrum Dresden-Rossendorf (HZDR) and the Kurt-SchwabeInstitut für Mess- und Sensortechnik e. V. Meinsberg (KSI). Special thanks go to Manja Vogel, Sabine Matys and Beate Katzschner. Thanks are also due to the BMBF for funding the BioNEWS project (FKZ: 03WKCL03D) within the framework of the Wachstumskern BioSAM. Furthermore the research was funded by the European Social Fund (ESF) (100284305).

Edited by: Gerald Gerlach

Reviewed by: two anonymous referees

\section{References}

Blüher, A., Ostermann, K., Jäckel, P., Clemens, A., Katzschner, B., Rödel, G., and Mertig, M.: Extraction and long-term storage of Slayer proteins and flagella from Lysinibacillus sphaericus NCTC 9602: Building blocks for nanotechnology, Eng. Life Sci., 15, 410-415, https://doi.org/10.1002/elsc.201400182, 2015.

Conroy, D. J., Millner, P. A., Stewart, D. I., and Pollmann, K.: Biosensing for the environment and defence: Aqueous uranyl detection using bacterial surface layer proteins, Sensors, 10, 47394755, 2010.

Fahmy, K., Merroun, M., Pollmann, K., Raff, J., Savchuk, O., Hennig, C., and Selenska-Pobell, S.: Secondary structure and Pd (II) coordination in S-layer proteins from Bacillus sphaericus studied by infrared and X-ray absorption spectroscopy, Biophys. J., 91, 996-1007, 2006.

Fano, U.: The theory of anomalous diffraction gratings and of quasistationary waves on metallic surfaces (Sommerfeld's waves), J. Opt. Soc. Am., 31, 213-222, 1941.

Geoghegan, W. D. and Ackerman, G. A.: Adsorption of horseradish peroxidase, ovomucoid and anti-immunoglobulin to colloidal gold for the indirect detection of concanavalin A, wheat germ agglutinin and goat anti-human immunoglobulin $\mathrm{G}$ on cell surfaces at the electron microscopic level: a new method, theory and application, J. Histochem. Cytochem., 25, 1187-1200, 1977.

Gleick, P. H.: Water in crisis: a guide to the world's fresh water resources, Oxford University Press, New York, USA, 1993.

Goldman, M. and Wilson, D. A.: Growth of Sporosarcina ureae in defined media, FEMS Microbiol. Lett., 2, 113-115, 1977.

Hofmann, A. and Danz, N.: Plasmon resonance sensor, Patent, WO/2008/025488, available at: https://patentscope.wipo. int/search/en/detail.jsf?docId=WO2008025488 (last access: 22 June 2018), 2008.

Homola, J., Yee, S., and Gauglitz, G.: Surface plasmon resonance sensors: review, Sensor. Actuat. B-Chem., 54, 3-15, 1999.

Horcas, I., Fernández, R., Gomez-Rodriguez, J. M., Colchero, J., Gómez-Herrero, J., and Baro, A. M.: WSXM: A software for scanning probe microscopy and a tool for nanotechnology, Rev. Sci. Instrum., 78, 013705, https://doi.org/10.1063/1.2432410, 2007.
Jankowski, U., Merroun, M. L., Selenska-Pobell, S., and Fahmy, K.: S-Layer protein from Lysinibacillus sphaericus JG-A12 as matrix for Au III sorption and Au-nanoparticle formation, Spectroscopy, 24, 177-181, 2010.

Kretschmann, E.: Die Bestimmung optischer Konstanten von Metallen durchAnregung von Oberflächenplasmaschwingungen, Z . Phys., 241, 313-324, 1971.

Kretschmann, E. and Raether, H.: Radiative decay of nonradiative surface plasmons excited by light, Zeitschrift für Naturforschung, Teil A, Astrophysik, Physik, Physikalische Chemie, 23, 2135-2136, 1968.

Ladenhauf, E. M., Pum, D., Wastl, D. S., Toca-Herrera, J. L., Phan, N. V., Lieberzeit, P. A., and Sleytr, U. B.: S-layer based biomolecular imprinting, RSC Adv., 5, 83558-83564, 2015.

Lakatos, M., Matys, S., Raff, J., and Pompe, W.: Colorimetric As (V) detection based on S-layer functionalized gold nanoparticles, Talanta, 144, 241-246, https://doi.org/10.1016/j.talanta.2015.05.082, 2015.

Mateu, B. P., Kainz, B., Pum, D., Sleytr, U. B., and Toca-Herrera, J. L.: Fluorescent sensors based on bacterial fusion proteins, Methods Appl. Fluores., 2, 024002, https://doi.org/10.1088/20506120/2/2/024002, 2014.

Mathew, R., Mulani, M. S., and Majumder, D. R.: Bacterial surface layer proteins: A key to metal biosorption, International Journal of Technical Research and Applications, 3, 177-180, 2015.

Matys, S., Raff, J., Soltmann, U., Selenska-Pobell, S., Böttcher, H., and Pompe, W.: Calcium dipicolinate induced germination of bacillus spores embedded in thin silica layers: novel perspectives for the usage of biocers, Chem. Mater., 16, 5549-5551, 2004.

Merroun, M., Raff, J., Rossberg, A., Hennig, C., Reich, T., and Selenska-Pobell, S.: Complexation of Uranium by Cells and Slayer Sheets of Bacillus sphaericus JG-A12, Appl. Environ. Microb., 71, 5532-5543, https://doi.org/10.1128/AEM.71.9.55325543.2005, 2005.

Neubauer, A., Pum, D., and Sleytr, U. B.: An amperometric glucose sensor based on isoporous crystalline protein membranes as immobilization matrix, Anal. Lett., 26, 1347-1360, 1993.

Neubauer, A., Hödl, C., Pum, D., and Sleytr, U. B.: A multistep enzyme sensor for sucrose based on S-layer microparticles as immobilization matrix, Anal. Lett., 27, 849-865, 1994.

Otto, A.: Excitation of nonradiative surface plasma waves in silver by the method of frustrated total reflection, Zeitschrift für Physik A Hadrons and nuclei, 216, 398-410, 1968.

Park, D. M., Reed, D. W., and Yung, M. C.: Bioadsorption of Rare Earth Elements through Cell Surface Display of Lanthanide Binding Tags, Environ. Sci. Technol., 50, 2735-2742, 2016.

Pollmann, K. and Matys, S.: Construction of an S-layer protein exhibiting modified self-assembling properties and enhanced metal binding capacities, Appl. Microbiol. Biot., 75, 1079-1085, https://doi.org/10.1007/s00253-007-0937-5, 2007.

Pollmann, K., Raff, J., Merroun, M., Fahmy, K., and SelenskaPobell, S.: Metal binding by bacteria from uranium mining waste piles and its technological applications, Biotechnol. Adv., 24, 58-68, https://doi.org/10.1016/j.biotechadv.2005.06.002, 2006.

Raff, J., Merroun, M. L., Roßberg, A., Hennig, C., and SelenskaPobell, S.: EXAFS study of Uranium (VI) Complexes Formed by Native and Recrystallized S-layers of the Bacillus sphaericus StrainsJG-A12andNCTC9602, FZR-Report, p. 36, 2002. 
Raff, J., Soltmann, U., Matys, S., Selenska-Pobell, S., Pompe, W., and Böttcher, H.: Biosorption of Uranium and Copper by Biocers, Chem. Materr., 15, 240-244, 2003.

Roosen-Runge, F., Heck, B. S., Zhang, F., Kohlbacher, O., and Schreiber, F.: Interplay of $\mathrm{pH}$ and binding of multivalent metal ions: charge inversion and reentrant condensation in protein solutions, J. Phys. Chem. B, 117, 5777-5787, 2013.

Scheicher, S. R., Kainz, B., Köstler, S., Suppan, M., Bizzarri, A., Pum, D., and Ribitsch, V.: Optical oxygen sensors based on Pt (II) porphyrin dye immobilized on S-layer protein matrices, Biosensors and Bioelectronics, 25, 797-802, 2009.

Selenska-Pobell, S., Panak, P., Miteva, V., Boudakov, I., Bernhard, G., and Nitsche, H.: Selective accumulation of heavy metals by three indigeneous Bacillus strains, B cereus, B megaterium and B sphaericus, from drain waters of a uranium waste pile, FEMS Microbiol. Ecol., 29, 59-67, 1999.

Soltmann, U., Raff, J., Selenska-Pobell, S., Matys, S., Pompe, W., and Böttcher, H.: Biosorption of heavy metals by sol-gel immobilized Bacillus sphaericus cells, spores and S-layers, J. Sol.-Gel Sci. Techn., 26, 1209-1212, 2003.

Suhr, M., Unger, N., Viacava, K. E., Günther, T. J., Raff, J., and Pollmann, K.: Investigation of metal sorption behavior of Slp1 from Lysinibacillus sphaericus JG-B53: a combined study using QCM-D, ICP-MS and AFM, BioMetals, 27, 1337-1349, 2014.

Suhr, M., Raff, J., and Pollmann, K.: Au-Interaction of Slp1 Polymers and Monolayer from Lysinibacillus sphaericus JG-B53-QCM-D, ICP-MS and AFM as Tools for Biomolecule-metal Studies, JoVE-J. Vis. Exp., 107, e53572, https://doi.org/10.3791/53572, 2016.
Turkevich, J., Stevenson, P. C., and Hillier, J.: A study of the nucleation and growth processes in the synthesis of colloidal gold, Discuss. Faraday Soc., 11, 55-75, 1951.

United Nations World Water Assessment Programme (UNWWAP): The United Nations World Water Development Report 2015: Water for a Sustainable World, United Nations Educational, Scientific and Cultural Organization, Paris, France, 2015.

Weinert, U., Vogel, M., Reinemann, C., Strehlitz, B., Pollmann, K., and Raff, J.: S-layer proteins as an immobilization matrix for aptamers on different sensor surfaces, Eng. Life Sci., 15, 710-720, 2015.

World Health Organization (WHO) and the United Nations Children's Fund (UNICEF): Progress on Drinking Water, Sanitation and Hygiene: 2017 Update and SDG Baselines, Geneva, 2017.

Wilson, R.: The use of gold nanoparticles in diagnostics and detection, Chem. Soc. Rev., 37, 2028-2045, 2008.

Wood, R.: On a remarkable case of uneven distribution of light in a diffraction grating spectrum, Philos. Mag., 4, 396-402, https://doi.org/10.1080/14786440209462857, 1902.

Yousten, A. A. and Wallis, D. A.: Batch and continuous culture production of the mosquito larval toxin of Bacillus sphaericus 2362, J. Ind. Microbiol., 2, 277-283, 1987.

Zhao, W., Brook, M. A., and Li, Y.: Design of gold nanoparticlebased colorimetric biosensing assays, Chem. Bio. Chem., 9, 2363-2371, 2008 